Dostępne online www.journals.wco.pl/los

Zeszyty Naukowe WCO, Letters in Oncology Science 2020;17(1):1-4

CrossMark
Praca poglądowa/Review paper
Letters in Oncology Science

ISSN 2543-6724

ZESZYTY NAUKOWE WIELKOPOLSKIEGO CENTRUM ONKOLOGII

\title{
Metody obrazowania i planowania w radioterapii-sprawozdanie z wybranych wystąpień na 37. spotkaniu ESTRO w Barcelonie.
}

\author{
Jagoda Zychowicz ${ }^{1}$ \\ ${ }^{1}$ Oddział Radioterapii i Onkologii Ginekologicznej z Izbą Przyjęć, Wielkopolskie Centrum Onkologii, Poznań, Polska
}

\section{Streszczenie}

W celu uaktualnienia wiedzy dotyczącej metod planowania i obrazowania w radioterapii dokonano analizy wybranych doniesień naukowych przedstawionych na 37. ESTRO FORUM konferencji Europejskiego Towarzystwa Radioterapii i Onkologii (European Society for Radiotherapy \& Oncology, ESTRO). Realizując panel wystąpień ustnych dla elektroradiologów w zakresie wiedzy na temat metod obrazowania poruszono między innymi zagadnienia dotyczące konturowania narządów krytycznych, które zostaną pokrótce opisane w tej pracy.

\section{Wstęp}

Podczas 37. Konferencji ESTRO w Barcelonie, w panelach wystąpień ustnych dla elektroradiologów poruszano tematykę związaną $\mathrm{z}$ zastosowaniem metod automatycznego konturowania narządów krytycznych. Prace obejmowały porównanie klasycznej metody wykonywania poszczególnych obrysów z metodą wykorzystującą algorytmy obliczeniowe.

Stowa kluczowe: radioterapia, elektroradiologia, planowanie radioterapii, obrazowanie, narządy krytyczne

Adres do korespondencji

Jagoda Zychowicz

Oddział Radioterapii i Onkologii Ginekologicznej z Izbą Przyjęć,

Wielkopolskie Centrum Onkologii, ul. Garbary 15, 61-866 Poznań, Polska

e-mail: jagoda.zychowicz@gmail.com 


\section{Prezentacja efektów konturowania narządów krytycznych dla nowotworów głowy i szyi z wykorzystaniem samouczącego się systemu DLC.}

Pierwsze z serii wystąpień o tej tematyce zostało poświęcone ocenie efektów konturowania narządów krytycznych dla nowotworów okolicy głowy i szyi z wykorzystaniem sztucznej inteligencji tzw. systemu DLC (Deep Learning Contouring, WorkflowBox 2.0 alpha, Mirada Medical Ltd, Oxford, Wielka Brytania).). Metoda auto- konturowania ma za zadanie skrócić czas potrzebny na wykonanie obrysów narządów krytycznych przy zachowaniu dokładności porównywalnej do manualnego konturowania. Ocenie poddano wykorzystanie multi- atlasu do automatycznego konturowania (ABAS ang. Atlas-based auto-segmentation), który dopasowywał obrysy wybranych narządów krytycznych na podstawie wcześniej zaimplementowanej bazie danych opartych na wcześniej okonturowanych badania iCT (ang. Initial Computed Tomography) na podstawie tomografii komputerowej do planowania leczenia (3o pacjentów) z systemem DLC wykorzystującym metodę głębokiego uczenia się (698 pacjentów). Analizie poddano obrysy 22 narządów krytycznych takich jak: chrząstka nalewkowata, tętnice szyjne, pień mózgu, móżdżek, mózg, żuchwa, jama ustna, ślinianki przyuszne i podżuchwowe, tarczyce, głośnia wraz z obszarem nadgłośniowym, mięśnie zwieracze gardła, przełyk i rdzeń kręgowy. Zestaw przypadków klinicznych był losowo podzielony na zestaw treningowy (549), zestaw do krzyżowego sprawdzania poprawności- cross- validation (40) i zestaw testowy (109) do szkolenia modelu DLC. System ten został porównany z automatyczną segmentacją (ABAS) opartą na wybranych 30 konturach wybranych z zestawów treningowych, aby automatycznie obrysować obrazy testowe. Ocenę różnic między obiema metodami automatycznego konturowania a metodą klasyczną dokonywano za pomocą wykorzystania dwóch współczynników- DICE (współczynnik podobieństwa zbiorowisk) i średniej symetrycznej AD (Average distance).

Wyniki, które uzyskano wskazują na większą spójność porównywanych konturów narządów krytycznych dla metody z wykorzystaniem algorytmu DLC (17 z 22) w porównaniu z metodą, w której opierano się na Multiatlasie. Duży zysk jakości obrysów obserwuje się szczególnie w przypadku narządów o dużej zmienności anatomicznej tj. np. ślinianki przyuszne i podżuchwowe, tarczyca oraz małych i wydłużonych struktur jak: tętnice szyjne, mięśnie zwieracze gardła. [2]

\section{Porównanie metod automatycznego konturowania narządów dla nowotworu prostaty.}

W prezentowanej pracy poświęcono uwagę analizie wykorzystania w protokołach radioterapeutycznych metody automatycznego konturowania i ich zależności od danej lokalizacji [1]. Czas poświęcany na zapoznanie się z systemem do auto-konturowania, zmusza badaczy do udoskonalania tej metody. W prelekcji skupiono się na porównaniu konturów narządów krytycznych oraz dodatkowo stworzonej strukturze jaka był balon endorektalny dla nowotworu prostaty wykonanych przy użyciu multi- atlasu (ABAS) i metody z wykorzystaniem systemu DLC. Do badania wykorzystano obrazy tomografii komputerowej wykonane u 124 pacjentów z rozpoznanym nowotworem prostaty. Porównywano ze sobą obrysy następujących narządów: pęcherza, prostaty, pęcherzyków nasiennych, odbytu, głów kości udowej oraz balona endorektalnego. Model DLC został wdrożony na 114 badaniach w tej grupie pacjentów. Pozostałe 10 badań traktowano jako zestaw testowy do oceny, natomiast 10 badań z zestawu treningowego zostało wykorzystane dla modelu ABAS, na których jako wzorzec, zostały wykonane automatyczne obrysy.

Z wykonanego porównania za pomocą algorytmów matematycznych wysunięto wniosek, że metoda DLC przewyższa metodę konturowania z wykorzystaniem Multi-atlasu (Tab.1). W celu zwiększenia ważności badania, należałoby je przeprowadzić na większej grupie. Dla pracy klinicznej ważne jest również zmierzenie jak dużą oszczędność mogłaby wygospodarować metoda automatycznego konturowania DLC. [3]

\section{Omówienie dokładności i efektywności w autokonturowaniu narządów krytycznych okolicy głowy i szyi przy użyciu multi- atlasu.}

Użycie w praktyce klinicznej metody opierającej się na wykorzystywaniu dostępnych w bazie danych obrysów poszczególnych narządów krytycznych jest w dalszym ciągu ograniczone ze względu na ich niską dokładność w odwzorowaniu. Poniższa praca opierała się na przedstawieniu wyników z pomiaru czasu 
Table 1: Summary statistics for quantitative meaures (median, interquartile range). Top: Ovenap measures. Bottom: Distance measures.

\begin{tabular}{|c|c|c|c|c|c|c|c|c|c|c|c|c|}
\hline \multirow{3}{*}{$\begin{array}{l}\text { measure } \\
\text { method }\end{array}$} & \multicolumn{4}{|c|}{ DSC } & \multicolumn{4}{|c|}{ Sen_index } & \multicolumn{4}{|c|}{ hict_index } \\
\hline & \multicolumn{2}{|c|}{ DLC } & \multicolumn{2}{|c|}{ ABAS } & \multicolumn{2}{|c|}{ DLC } & \multicolumn{2}{|c|}{ ABAS } & \multicolumn{2}{|c|}{$D L C$} & \multicolumn{2}{|c|}{ ABAS } \\
\hline & med & zar & med & $i g r$ & med & igr & med & ior & med & iqur & med & igr \\
\hline proseate & 0.84 & 0.06 & 0.81 & 0.12 & 0.82 & 0.14 & 0.75 & 0.19 & 0.91 & 0.12 & 0.85 & 0.11 \\
\hline seminalvess & 0.62 & 0.23 & 0.41 & 0.25 & 0.56 & 0.37 & 0.27 & 0.23 & 0.59 & 0.20 & 0.72 & 0.12 \\
\hline bladder & 0.9 .4 & 0.03 & 0.82 & 0.08 & 0.94 & 0.05 & 0.92 & 0.11 & 0.95 & 0.07 & 0.77 & 0.14 \\
\hline inemer 1 & 0.94 & 0.01 & 0.94 & 0.02 & 0.91 & 0.04 & 0.91 & 0.04 & 0.96 & 0.03 & 0.96 & 0.03 \\
\hline temer & 0.95 & 0.00 & 0.93 & 0.02 & 0.90 & 0.02 & 0.91 & 0.04 & 0.97 & 0.02 & 0.97 & 0.01 \\
\hline gnes & 0.79 & 0.07 & 0.63 & 0.11 & 0.70 & 0.15 & 0.49 & 0.12 & 0.95 & 0.13 & 0.98 & 0.04 \\
\hline talloon & 0.97 & 0.03 & 0.98 & 0.03 & 0.56 & 0.01 & 0.98 & 0.01 & 0.99 & 0.01 & 0.98 & 0.02 \\
\hline
\end{tabular}

\begin{tabular}{|c|c|c|c|c|c|c|c|c|c|c|c|c|}
\hline \multirow{3}{*}{$\begin{array}{l}\text { measure } \\
\text { method }\end{array}$} & \multicolumn{4}{|c|}{ RMSO } & \multicolumn{4}{|c|}{$A D$} & \multicolumn{4}{|c|}{$H D$} \\
\hline & \multicolumn{2}{|c|}{ DLC } & \multicolumn{2}{|c|}{ ABAS } & \multicolumn{2}{|c|}{ DLC } & \multicolumn{2}{|c|}{ ABAS } & \multicolumn{2}{|c|}{$D L C$} & \multicolumn{2}{|c|}{ ABAS } \\
\hline & med & jar & med & $i g r$ & med & igr & $\operatorname{med}$ & ior & med & ingr & med & $i g r$ \\
\hline pocostate & 1.5 & 0.2 & 1.7 & 1.4 & 0.8 & 0.1 & 0.8 & 0.7 & 6.6 & 2.6 & 8.0 & 4.5 \\
\hline eominolvest & 1.2 & 0.3 & 1.2 & 0.4 & 0.6 & 0.1 & 0.5 & 0.1 & 6.0 & 1.3 & 5.8 & 1.3 \\
\hline blasdor & 1.2 & 1.1 & 3.5 & 0.8 & 0.5 & 0.3 & 1.4 & 0.5 & 10.2 & 5.4 & 17.8 & 5.1 \\
\hline tanner_1 & 0.8 & 0.1 & 0.9 & 0.2 & 0.4 & 0.1 & 0.4 & 0.1 & 4.3 & 1.0 & 4.6 & 1.5 \\
\hline tomer $r$ & 0.7 & D. 1 & 0.9 & 0.4 & 0.3 & 0.1 & 0.4 & 0.1 & 4.3 & 0.6 & 6.4 & 29 \\
\hline sens & 0.9 & 0.3 & 1,4 & 0.5 & 0.4 & 0.1 & 0.6 & 0.2 & 4.0 & 2.0 & 8.0 & 2.5 \\
\hline Evalloon & 0.6 & 0.6 & 0.6 & 0.6 & 0.3 & 0.2 & 0.2 & 0.2 & 4.0 & 5.5 & 5.8 & 3.5 \\
\hline
\end{tabular}

poświęconego na konturowanie narządów krytycznych z wykorzystaniem Multi atlasu ABAS (Mirada Medical, Oxford, UK) w porównaniu z konturami wykonanymi manualnie.

Wykorzystano badania tomograficzne 57 pacjentów z nowotworami gardła dolnego i krtani oraz zastosowano podział na dwie grupy: niski stopień zaawansowania klinicznego (T1-T2/No-1, n=30 pkt.) i duże zaawansowanie kliniczne $(\geq \mathrm{T} 3 / \geq \mathrm{N} 2 \mathrm{a}, \mathrm{n}=27$ pkt.) Wszystkie obrysy manualne wykorzystane do porównania były wykonane przez eketroradiologa w systemie Eclipse. Podstawowy Multi atlas dla każdej z grup składał się z pierwszych 10 przypadków referencyjnych („Man”). Dla następnych 10 pacjentów (11-20) kontury zostały wygenerowane automatycznie („Mir”) i manualnie poprawione („MirCor”). Dla pozostałych pacjentów (21-30 dla T1-T2, 21-27 dla T3+) użyto rozszerzonego Multi atlas (składający się z przypadków 1-20) . Dla wszystkich tych grup wykonano obrysy następujących narządów krytycznych: mózgowie, pień mózgu, oczy, soczewki, nerwy wzrokowe, przysadka mózgowa, żuchwa, ślinianki, ślinianki podżuchwowe, rdzeń kręgowy, zwężenie gardła górnego, przełyk, tarczycę, jamę ustną, płuca, tchawicę, co daje łącznie 16 narządów. Czas potrzebny na wykonanie konturów tych narządów w każdej z grup („Man”,"Mir” i MirCor”) został zebrany i porównany za pomocą metod statystycznych.

Średni czas potrzebny na wykonanie konturów w pierwszej grupie („Man”) wynosił 19.6 \pm 2.3 min, podczas

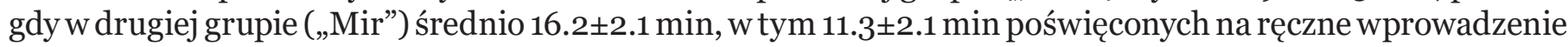
poprawek przez elektroradiologa. Zwiększenie liczby przypadków w Multi atlasie dało zysk
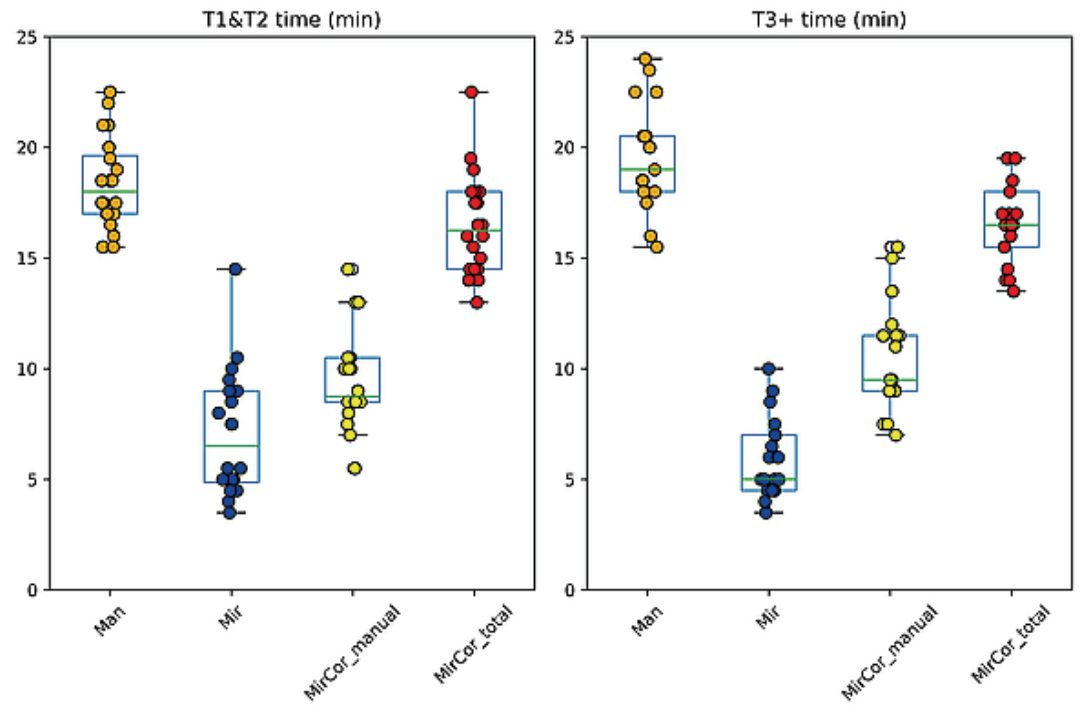

Wykres 1 Korelacja czasu poświęconego na wykonanie obrysów narządów krytycznych w zależności od zawansowania klinicznego. [4] 
kolejnych 3 min na pacjenta, co prowadzi do skrócenia czasu wykonywania konturów narządów krytycznych prawie o połowę. Nie stwierdzono różnicy w czasie poświęconym na wykonanie tych samych konturów dla grup o różnym zaawansowaniu klinicznym (wykres 1) .

Na podstawie przedstawionych badań wysunięto następujące wnioski:

- Multi-atlas ABAS wykorzystany do wykonywania obrysów narządów krytycznych w regionie głowy i szyi w połączeniu z manualną korekcją pozwala na znaczący zysk w czasie poświęconym na tę czynność.

- Poprzez zwiększanie liczby przypadków klinicznych, z których korzysta multi atlas, osiągnięto krótszy czas, bez znaczącego wpływu na poprawę dokładności.

- Stopień klinicznego zaawansowania choroby nie ma istotnego wpływu na czas.[4]

\section{Podsumowanie}

Wybrane wystąpienia ustne przedstawione w ramach corocznej konferencji ESTRO w panelu dla elektroradiologów, rzucają nowe światło na wyzwania, jakie wiążą się z rożnymi metodami konturowania narządów krytycznych, w tym metod z wykorzystaniem samouczących się modeli oraz możliwości jakie niesie wykorzystanie sztucznej inteligencji w medycynie. Z całą pewnością powinniśmy rozważyć wykorzystywanie nowych rozwiązań technologicznych, gdyż jak pokazano pozwalają one znacząco skrócić czas wykonywania obrysów, a tym samym skrócić czas przygotowywania planów leczenia. Z całą pewnością matematyczne modele obliczeniowe coraz częściej będą towarzyszyły nam w życiu codziennym co niewątpliwie przyczyni się postępu myśli technologicznej.

\section{Finansowanie/ Financial suport}

Artykuł został sfinansowany z grantu Wielkopolskiego Centrum Onkologii w Poznaniu, nr 8/2018 (186); 6/03/2018/ZRII/oo8

\section{Piśmiennictwo / References}

[1] Perspectives onautomated image segmentation for radiotherapy. Sharp G, et al. Vision 20/20, Med.Phys. 2014;41(5)

[2] Quantitative evaluation of deep learning contouring of head and neck organs at risk H. Bakker, D. Peressutti, P. Aljabar, L.V. Van Dijk, L. Van den Bosch, M. Gooding, C.L. Brouwer, Abstrakt book, Radiotherapy and Oncology, Journal of European Society for Radiotherapy and Oncology, Volume 127, Suplement 1(2018) ISSN 0167-8140

[3] Comparison of auto-contouring methods forregions of interest in prostate CTP. Aljabar, D. Peressutti, E. Brunenberg, R. Smeenk,R. Van Leeuwen2, M. Gooding, Abstrakt book, Radiotherapy and Oncology, Journal of European Society for Radiotherapy and Oncology, Volume 127, Suplement 1 (2018), ISSN 0167- 8140

[4] Multi-atlas auto-segmentation for head and neck OARs: accuracy and time efficiency D. Gugyerás, A. Farkas, M. Peto, J. Hadjiev, A.Gulyban, F. Lakosi, Abstrakt book, Radiotherapy and Oncology, Journal of European Society for Radiotherapy and Oncology, Volume 127, Suplement 1(2018), ISSN 0167- 8140 